\title{
Comparison of computer simulation and graphical illustration for teaching experimental pharmacology to undergraduate students
}

\author{
Gurleen Kaur ${ }^{1 *}$, Preeti Garg ${ }^{1}$, Vidushi Sharma ${ }^{1}$, Jaspreet Singh ${ }^{2}$, \\ Prithpal S. Matreja ${ }^{3}$, P. M. L. Khanna ${ }^{1}$
}

${ }^{1}$ Department of Pharmacology, Gian Sagar Medical College and Hospital, Banur, Punjab, India ${ }^{2}$ Medical Officer, Civil Hospital, Rajpura, Punjab, India ${ }^{3}$ Department of Pharmacology, Teerthanker Mahaveer Medical College and Research Centre, Moradabad, India

Received: 19 March 2017 Accepted: 17 March 2017

*Correspondence to:

Dr. Gurleen Kaur,

Email: gurleenselhi@gmail.com

Copyright: (C) the author(s), publisher and licensee Medip Academy. This is an openaccess article distributed under the terms of the Creative Commons Attribution NonCommercial License, which permits unrestricted noncommercial use, distribution, and reproduction in any medium, provided the original work is properly cited.

\begin{abstract}
Background: Nowadays, medical schools all over the world are incorporating newer methods of teaching experimental pharmacology like computer simulation, besides using graphs, charts, didactic lectures. The present study compared the effectiveness and acceptance of two commonly used methods, namely, computer simulation and graphical illustration in teaching experimental pharmacology to undergraduate medical students.

Methods: 90 students of 2nd Prof MBBS were divided into 2 groups and were given either computer simulation or graphical illustration via a cross-over design at two settings, which was followed by a post-test for that particular session. Feedback was taken from the students and the faculty. The data obtained was analyzed using descriptive statistics.

Results: The average marks scored by the students in sessions using CAL $(67.8 \%)$ was significantly high $(\mathrm{p}=0.008)$ as compared to teaching by graphical illustrations $(60.4 \%) .71 \%$ of students found CAL improved their learning skills better than graphical illustrations. $85 \%$ students and $80 \%$ faculty agreed that there should be a judicious mixture of CAL and graphical illustrations for a better understanding of drugs.

Conclusions: CAL is a beneficial and effective learning tool in teaching experimental pharmacology. For better understanding, graphical illustrations should be used as an adjuvant to CAL.
\end{abstract}

Keywords: Computer assisted learning, Experimental pharmacology, Faculty, Feedback, Graphical illustration, Students

\section{INTRODUCTION}

Pharmacology is one of the fundamental building blocks to rational therapeutics, which helps the student to apply the knowledge of drugs in the clinical setting during his interaction with patients. ${ }^{1,2}$ Many attempts have been made by various colleges all over India and abroad to make the teaching-learning of pharmacology more absorbing and appropriate. Similarly, changes have been done to make theory and practical teaching go hand in hand. ${ }^{3,4}$ To be in tune with the current knowledge and technology, it is imperative to review the various teaching methods available periodically. ${ }^{2}$ In the recent years, the undergraduate training in pharmacology has made progression with the use of several new teaching techniques namely small group discussions, problem based learning, role play demonstration, case based learning, software programs like Computer assisted learning (CAL), graphical illustrations, clinical pharmacology studies. ${ }^{5-8}$ Student feedback plays a vital role in the implementation of newer teaching learning methods.

With the ban of animal experiments for teaching and learning in medical colleges in India, the scope of experimental pharmacology has become limited. ${ }^{10-13}$ 
There is need to think and create new alternatives to animal experiments. The experimental pharmacology has come a long way and has evolved from live animal experiments to various computer simulation modules, graphical illustrations, audio-visual aids, mannequinbased simulation. ${ }^{14-17}$

A large number of studies from several medical colleges have documented CAL as an effective tool as regards to its usefulness in providing knowledge as well as in attaining learning objectives. ${ }^{7,18-21}$ Consequently, CAL is being implemented now and is the most widely used invaluable component of experimental pharmacology in medical colleges. ${ }^{7,22,23}$ It is a software of simulated experiments, which provides interactive instructions pertaining to a particular subject in a user friendly manner. $^{18}$

CAL models give non-conflicting results without any experimental errors, as compared to conventional animal experiments. ${ }^{7}$ A large number of students can perform the experiment simultaneously. The effects of a large number of drugs (at varying dose ranges) which are reproducible, can be clearly visualized in CAL in a relatively short period of time. ${ }^{10,18}$ There are certain disadvantages with the use of CAL. There is no direct interaction with the living tissue. The software has prefixed doses which hinders the students to observe biological response at desired doses. Use of CAL software requires infrastructure, funds, trained faculty and frequent upgrading. ${ }^{18,19,24}$

Though CAL mimics the actual experimental set up in the laboratory, the financial constraints involved with the setting up of CAL is discouraging to the acceptance of CAL in medical colleges of India. ${ }^{10,24}$ One of the cheapest alternatives is using graphical illustrations, which are preformed and are available easily both as hard and soft versions. These illustrations depict the effect of various drugs on the intact or isolated animal tissue in the form of graphs and charts. The response to a number of drugs can be demonstrated, which may be tabulated for better understanding. The use of graphs is cost-effective and consumes less time. Students can download these from the internet or get them photocopied for future practice. Like in CAL, direct interaction of students with animal tissue is not there, which may be a hindrance to learning and memorizing. Also, the response is with prefixed doses.

Learning with CAL as well as graphical illustrations helps the students to understand the subject better i.e. improves the observational and analytical abilities rather than psychomotor skill acquisition. ${ }^{25}$ In addition; teaching with CAL or graphical illustrations saves time, which the students can now utilize for clinically oriented practical classes.

Most of the studies conducted show the utility of CAL for teaching experimental pharmacology, often comparing it with live animal experiments. However, there is dearth of studies which compare CAL with the other very commonly used tool for teaching experimental pharmacology i.e. graphical illustrations.

Therefore, the present study was designed and conducted to compare the effectiveness and acceptance of the two very commonly used teaching methods of experimental pharmacology-CAL and graphical illustration, in undergraduate students of $2^{\text {nd }}$ professional MBBS.

\section{METHODS}

The cross-sectional study was conducted in September 2016 in the Department of Pharmacology, Gain Sagar Medical College \& Hospital, Punjab, after approval from Institutional ethics committee (IEC).

A sensitization programme for faculty and students regarding the study was done. The feedback questionnaires for the students and faculty were developed and validated. The student feedback questionnaire consisted of 10 questions on a 5-point likert scale (1=strongly disagree, 2=disagree, $3=$ neutral, $4=$ agree, $5=$ strongly agree) given in annexure 1 . The faculty feedback questionnaire had 5 questions on the 5point likert scale. The students and the faculty who participated in the pilot study for questionnaire validation were excluded.

Ninety students of $2^{\text {nd }}$ Professional MBBS $\left(3^{\text {rd }}\right.$ semester) were divided into 2 groups: Group A and Group B. Group A was taught the effect of drugs (miotics, mydriatics and local anaesthetics) on rabbit eye with CAL. The software used was ExPharma-a computer simulation software program designed by Dr. R. Raveendran, JIPMER. Group B was taught the same topic using graphical illustrations. Both the groups were then evaluated by a test, which included multiple choice and one-word answer questions.

In the subsequent class, cross-over of the students was done and the effect of drugs (stimulants and depressants) on frog's heart was taught. The group A students were now taught using graphical illustrations and group B using CAL method. This was followed by a similar test to evaluate their performance.

After the test, the pre-validated feedback questionnaire was filled by all the students (both group A and B) anonymously. The questionnaire was administered to know their perceptions regarding the usefulness and preference for the two methods of learning and understanding of experimental pharmacology. Feedback was also taken from the teaching faculty regarding the two teaching-learning methods, in the form of the prevalidated questionnaire, as shown in annexure 2.

The data obtained was analyzed using descriptive statistics and the results were expressed as percentage. 


\section{RESULTS}

Of the 90 students of $3^{\text {rd }}$ semester, 40 students were males and 50 females with mean age of $19.3 \pm 1.3$ years.

\section{Student marks evaluation}

Regarding the outcome of the test, the average marks scored by the students when taught using CAL and graphical illustrations was $67.8 \%( \pm 1.78)$ and $60.4 \%$ $( \pm 1.93)$ respectively, as shown in Figure 1 . There was significant difference between the marks scored in the two teaching-learning methods $(\mathrm{p}=0.008)$.

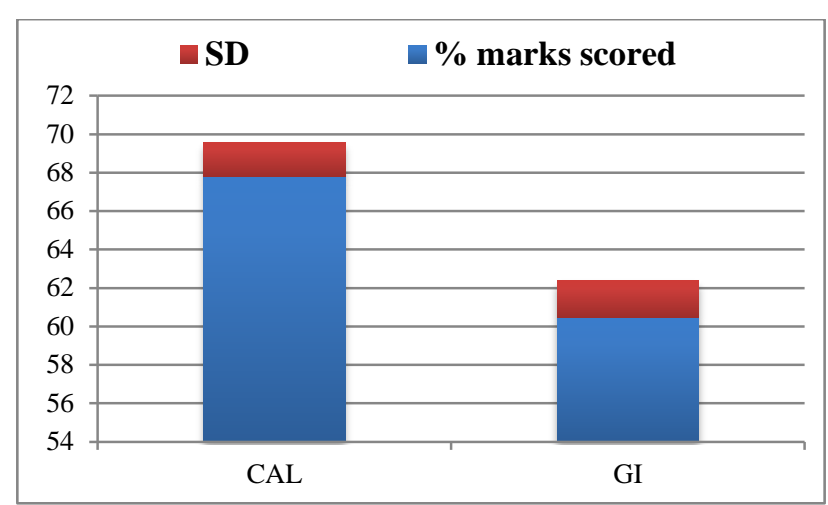

CAL: Computer assisted learning

GI: Graphical illustration

Figure 1: Comparison of average marks scored by the students when taught using CAL and graphical illustration.

\section{Student feedback}

Majority of students $(81 \%)$ agreed that CAL was useful in the understanding of the topic of experimental pharmacology. 55\% think that they were more involved and motivated to learn more using CAL.

The drugs could be better related with their basic mechanisms with CAL was agreed upon by $65 \%$ students. More than half of the students $(61 \%)$ agree that the CAL improved their ability to apply concepts of basic sciences to clinical situations. $71 \%$ observed that $\mathrm{CAL}$ improved their learning skills better than graphical illustrations.

Only $43 \%$ agree that training with CAL will help them in preparing better for the final university examination. $65 \%$ believe that the time allocated to both the sessions was adequate and $85 \%$ said that there should be a judicious mixture of CAL and graphical illustrations for better understanding of effect of drugs. $82 \%$ think that all CAL sessions should be preceded by graphical illustrations to help understand the concepts of experimental pharmacology better. $91 \%$ students think that such sessions would increase their interest in pharmacology. The item-wise responses to the student feedback questionnaire are shown in Figure 2.

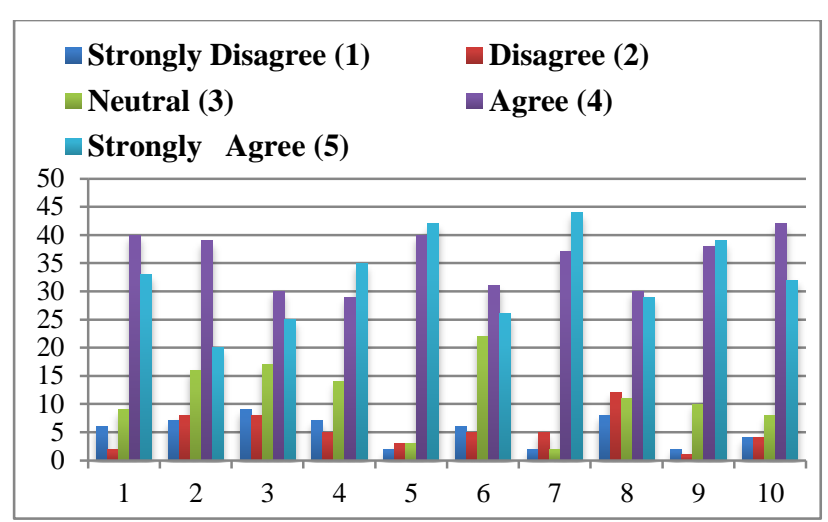

Figure 2: The response to the student feedback questionnaire.

\section{Faculty feedback}

The faculty feedback was taken to assess the faculty's acceptance of the two teaching methods of experimental pharmacology. The perception of faculty regarding teaching by both the methods is shown in Figure 3 .

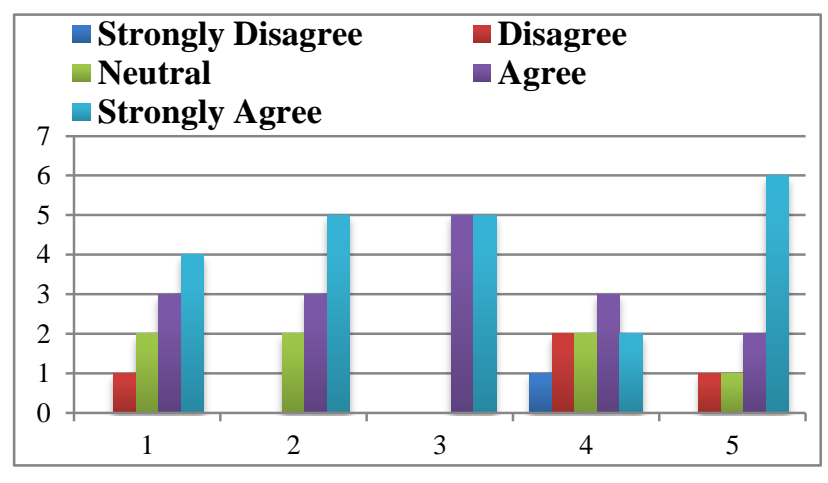

Figure 3: The response to the faculty feedback questionnaire.

The majority of faculty (70\%) agreed that the students were more attentive and interactive during CAL sessions in comparison to teaching with graphical illustrations. $80 \%$ faculty observed that students could understand and correlate better after CAL. Whole faculty (100\%) believed that CAL requires expertise to handle technical errors related to computers and $50 \%$ faculty observed $\mathrm{CAL}$ to be more time consuming. Overall, the faculty $(80 \%)$ supported the use of CAL in experimental pharmacology along with graphical illustrations.

\section{DISCUSSION}

Various teaching methods have come into play for benefit of the students as involvement of students improves learning and thereby, their performance in test and ultimately, the university examinations. ${ }^{26}$ In the present study, the average score in the test conducted to evaluate the students' performance was significantly higher in CAL group compared to score obtained by students when teaching was done using graphical illustrations $(\mathrm{p}=0.008)$. 
The higher average score in CAL group teaching may be because here, the students were more attentive and showed more interest. This is supported by other studies, which showed improved scores $(65 \%, 75 \%)$ with the use of CAL. ${ }^{19,27}$

In a study conducted by Satish et al, $78 \%$ of the students had a preference for CAL as a teaching tool for experimental pharmacology whereas only $65 \%$ students wanted teaching in experimental pharmacology to be done with the help of graphical illustrations. ${ }^{17}$ In the present study also, $71 \%$ students agreed that $\mathrm{CAL}$ sessions were more helpful in improving their learning skills as compared to learning with the help of graphical illustrations.

In this study, $81 \%$ of the students opined that CAL was useful in understanding the concepts of experimental pharmacology, which is corroborated by a study conducted by Saurabh et al, in which $63 \%$ students found CAL helpful in understanding the concepts of experimental pharmacology. ${ }^{28}$ Another survey conducted in the form of a questionnaire by Govindraja et al indicated that $>80 \%$ of the students found the simulations to be good and $75 \%$ claimed that their understanding had improved. ${ }^{19} 58 \%$ students found CAL to be good and useful in learning of experimental pharmacology, as reported by Babu et al. ${ }^{29}$

According to a study conducted by Kuruvilla et al on the use of CAL, $99 \%$ students thought CAL to be an effective method of teaching practical aspects of experimental pharmacology, which correlates well with our study ( $81 \%$ students agreed to this), as well as a study by Sharma et al in which $90 \%$ students gave the same opinion. $^{10,27}$ In a study by Babu et al, majority of the students observed that CAL is highly effective in imparting knowledge of experimental pharmacology. ${ }^{29}$ Exploring the views of students regarding advantages of using CAL, 91\% students in the present study observed that CAL would increase their interest in pharmacology, as compared to another study by Kuruvilla, where $100 \%$ students found learning with CAL interesting. ${ }^{10}$ Additionally, findings similar to present study $(85 \%)$ were reported by other studies where majority of the students $(90 \%, 87 \%, 84 \%)$ agreed to the fact that CAL should be conducted as an adjuvant to practical classes, and there should be a judicious mixture of the two. ${ }^{10,27,29}$

In the present study, majority of the students $(65 \%)$ found that they could learn more using CAL and the drugs could be better related with their basic mechanisms which goes in accordance with the results of other studies where majority of the students observed that they had achieved their learning objectives with the use of CAL. ${ }^{10,19,29}$

The students were in favor of having more of CAL sessions in their practical classes to improve their understanding of concepts of experimental pharmacology. However, in most of the studies, the students expressed that lack of interaction with living tissues and animals is the main drawback while learning with both the methods. According to study by Ahirwar, $42 \%$ students said that CAL contribute more to understanding theoretical concepts than laboratory practical, while in our study, $65 \%$ students agreed that drugs were better related with their basic mechanisms, when teaching was done through CAL. ${ }^{30}$ The difference in the opinion could be due to the fact that the study was done comparing CAL with live animal experiments, whereas present study compared use of CAL with graphical illustrations. Teaching with the help of graphs is more like didactic lecture where students are passive recipients of knowledge while teaching with the help of CAL is more virtual, interactive and reproduces response seen in live experiments. Interactive sessions have more potential to enhance the learning and memorizing ability of the students. The present study is a step towards assessing the student's attitude, perception and feedback on teaching-learning methodology and evaluation methods in pharmacology. The effective implementation of CAL needs orientation and support for the teaching faculty to adopt this teaching modality and to use it to optimize and enhance students' learning experience. Limitations of the study-It should be conducted on a larger number of students. Also, more experiments covering different topics can be demonstrated and varied graphical illustrations showing effect of a wide range of drugs at different doses can be used.

In the end, our study concluded that CAL is an excellent beneficial tool to demonstrate the response of various drugs in animals and helps meet the learning objectives as well. CAL gives a near to real idea of actual experimentation. Using CAL would definitely prove useful and will make learning easier. But, at the same time, there is need for training of faculty regarding use of CAL software. Time to time up gradation of the software with an efficient technical backup is also required. However more studies need to be done to evaluate the effectiveness of other teaching methods available.

\section{ACKNOWLEDGEMENTS}

Authors are highly thankful to the entire faculty and supporting staff of the Department of Pharmacology, without whose support, this study could not have been possible. Authors are also grateful to the participating students of $2^{\text {nd }}$ Professional MBBS, for their co-operation and active interest in the conduct of the study.

Funding: No funding sources

Conflict of interest: None declared

Ethical approval: The study was approved by the Institutional Ethics Committee

\section{REFERENCES}

1. Vasundara K, Kanchan P, Pundarikaksha HP, Girish K, Prassana S, Jyothi R. An imperative need to 
change pharmacology curriculum: A pilot survey. Indian J Pharmacol. 2010;42(6):420.

2. Bhosale UA, Yegnanarayan R, Yadav GE. Attitude, perception and feedback of second year medical students on teaching-learning methodology and evaluation methods in pharmacology: A questionnaire-based study. Niger Med J. 2013;54(1): 33-9.

3. Achike FI, Ogle CW. Information overload in the teaching of pharmacology. J Clin Pharmacol. 2000; 40(2):177-83.

4. Gitanjali B, Shashindran CH. Curriculum on clinical Pharmacology for medical undergraduates of India. Indian J Pharmacol. 2006;38:S108-14.

5. Badyal DK, Modgill V, Kaur J. Computer simulation models are implementable as replacements for animal experiments. Altern Lab Anim. 2009;37:191-5.

6. Akbarsha MA, Zeeshan M, Meenakumari KJ. Alternatives to animals in education, research and risk assessment: An overview with special reference to Indian context. ALTEX Altern Anim Ex. 2013; 2:5-19.

7. John LJ. A review of computer assisted learning in medical undergraduates. J Pharmacol Pharmacother 2013;4(2):86-90.

8. Sharma R, Verma U, Kapoor B, Chopra VS. Novel teaching approaches in Pharmacology. JK Science 2004;6(3):172-3.

9. Colbert-Getz JM, Baumann S. Changing medical students' perception of the evaluation culture: Is it possible? J Educ Eval Health Prof. 2016;13:8.

10. Kuruvilla A, Ramalingam S, Bose AC, Shastri GV, Bhuvaneswari K, Amudha G. Use of computer assisted learning as an adjuvant to practical pharmacology teaching: Advantages and limitations. Indian J Pharmacol 2001;33:272-5.

11. Greenhalgh T. Computer assisted learning in undergraduate medical education. BMJ. 2001;322: 40-4.

12. Hansen LA, Boss GR. Use of live animals in the curricula of US Medical Schools: Survey results from 2001. Acad Med 2002;77(11):1147-9.

13. Naeem SS, Rizvi W, Kumar A. Revisiting undergraduate practical pharmacology. J Pharmacol Pharmacother 2012;3(1):76-9.

14. Medical Council of India, New Delhi. Amendment notification on 8 July 2009 in the Minimal Standard Requirements for the Medical College with 150 admissions annually, Regulations; 1999.

15. Badyal DK, Desai C. Animal use in pharmacology education and research: The changing scenario. Indian J Pharmacol. 2014;46(3):257-65.

16. Vasundara K, Pundarikaksha HP, Vijendra R, Girish $\mathrm{K}$, Jyothi R, Srinivasa P. Existing and expected practical medical pharmacology curriculum - A survey. J Clin Diagnostic Res. 2011;5(2):340-3.

17. Satish GR, Kamath L, Jayanthi CR. Reassessment of dispensing pharmacy and animal experiments in undergraduate practical pharmacology curriculum: feedback from students. Int $\mathbf{J}$ Basic Clin Pharmacol 2016;5(2):285-92.

18. Sharma D, Malhotra P. A comparison of computer assisted learning and practical animal experiment for undergraduate medical students in pharmacology curriculum- a questionnaire based study conducted in a medical college of North India. JK Sci. 2016; 18(2):116-9.

19. Govindaraja C, Jaiprakash H, Annamalai C, Vedhavathy SS. Computer assisted learning: Perceptions and knowledge skills of undergraduate medical students in a Malaysian medical school. Natl J Physiol Pharm Pharmacol. 2011;1(2):63-7.

20. Dewhurst DG, Hardcastle J, Hardcastle PT, Stuart E. Comparison of a computer simulation program and a traditional laboratory practical class for teaching the principles of intestinal absorption. Adv Physiol Educ. 1994;12(1):S95-104.

21. Dewhurst D. Is it possible to meet the learning objectives of undergraduate pharmacology classes with non-animal models? AATEX 2008;14:207-12.

22. Pukhta MA, Bhat MY, Singh Z. A questionnaire based study of prevailing teaching methods in pharmacology and its efficacy/evaluation by second professional MBBS students. Int J Res Med Sci. 2016;4(6):2218-23.

23. Moss S. Computer technology in education. Pharm J. 1993;251:491.

24. Desai M. Changing face of pharmacology practicals for medical undergraduates. Indian $\mathrm{J}$ Pharmacol. 2009; 41:151-2.

25. Haq I, Dacre J. Computer-assisted learning in undergraduate and postgraduate rheumatology education. Rheumatology. 2003;42:367-70.

26. Kaufman M, Mann V. Achievement of students in a conventional and problem based learning (PBL) curriculum. Adv Health Sci Educ Theory Pract. 1999; 4:245-60.

27. Sharma T, Bala S, Garg R, Kalra J. Use of Computer Assisted Learning as an Alternative to Experimental Pharmacology Teaching: Student's Opinion. JK Science 2016; 18(2): 116-19.

28. Saurabh MK, Agrawal J. The opinion of undergraduate medical students on current curriculum and teaching methodology of pharmacology in four medical colleges of India: a questionnaire based study. Int $\mathbf{J}$ Basic Clin Pharmacol. 2015;4(5):970-75.

29. Babu KR, Singh AH, Palla J. Computer Assisted Learning: Perception And Acceptability Of Undergraduate Medical Students In Pharmacology Experiments. JEMDS 2015;102(4):16761-4.

30. Ahirwar M, Sinha A, Shakya A, Kumar V. Computer assisted learning in pharmacology: an update. 1-34.

Cite this article as: Kaur G, Garg P, Sharma V, Singh J, Matreja PS, Khanna PML. Comparison of computer simulation and graphical illustration for teaching experimental pharmacology to undergraduate students. Int J Basic Clin Pharmacol 2017;6:788-94. 


\section{Annexure 1: Student Feedback questionnaire}

The following questions are to be answered on a scale of 1-5. Please tick your response to each item

1=Strongly Disagree, 2=Disagree, 3=Neutral, 4=Agree, 5=Strongly Agree

\begin{tabular}{|c|c|c|c|c|c|c|}
\hline & Questions & $\begin{array}{l}\text { Strongly } \\
\text { Disagree } \\
\text { (1) }\end{array}$ & $\begin{array}{l}\text { Disagree } \\
\text { (2) }\end{array}$ & $\begin{array}{l}\text { Neutral } \\
\text { (3) }\end{array}$ & $\begin{array}{l}\text { Agree } \\
\text { (4) }\end{array}$ & $\begin{array}{l}\text { Strongly } \\
\text { Agree (5) }\end{array}$ \\
\hline 1 & CAL was useful in the understanding of the topic & & & & & \\
\hline 2 & $\begin{array}{l}\text { By virtue of CAL, the drugs could be better related } \\
\text { with their basic mechanisms. }\end{array}$ & & & & & \\
\hline 3 & $\begin{array}{l}\text { CAL improved my ability to apply concepts of } \\
\text { basic sciences to clinical situations. }\end{array}$ & & & & & \\
\hline 4 & $\begin{array}{l}\text { CAL improved my learning skills better than } \\
\text { graphical illustrations }\end{array}$ & & & & & \\
\hline 5 & $\begin{array}{l}\text { CAL sessions would increase my interest in } \\
\text { pharmacology }\end{array}$ & & & & & \\
\hline 6 & $\begin{array}{l}\text { Training with CAL will help me in preparing } \\
\text { better for the final university examination }\end{array}$ & & & & & \\
\hline 7 & $\begin{array}{l}\text { We were more involved and motivated to learn } \\
\text { more using CAL. }\end{array}$ & & & & & \\
\hline 8 & $\begin{array}{l}\text { The time allocated to all the sessions was } \\
\text { adequate. }\end{array}$ & & & & & \\
\hline 9 & $\begin{array}{l}\text { There should be a judicious mixture of CAL and } \\
\text { graphical illustrations for better understanding of } \\
\text { drugs }\end{array}$ & & & & & \\
\hline 10 & $\begin{array}{l}\text { CAL sessions should be preceded by graphical } \\
\text { illustrations. }\end{array}$ & & & & & \\
\hline
\end{tabular}


Annexure 2: Faculty Feedback Questionnaire

\begin{tabular}{|l|l|l|l|l|l|l|}
\hline & Questions & $\begin{array}{l}\text { Strongly } \\
\text { Disagree (1) }\end{array}$ & $\begin{array}{l}\text { Disagree } \\
(\mathbf{2})\end{array}$ & $\begin{array}{l}\text { Neutral } \\
\text { (3) }\end{array}$ & $\begin{array}{l}\text { Agree } \\
\text { (4) }\end{array}$ & $\begin{array}{l}\text { Strongly } \\
\text { Agree (5) }\end{array}$ \\
\hline 1 & $\begin{array}{l}\text { Students were more attentive and interactive during } \\
\text { CAL sessions }\end{array}$ & & & & \\
\hline 2 & $\begin{array}{l}\text { Students could understand and correlate better after } \\
\text { CAL }\end{array}$ & & & & & \\
\hline 3 & $\begin{array}{l}\text { The teaching with CAL required expertise/training } \\
\text { in CAL software }\end{array}$ & & & & & \\
\hline 4 & Time required to teach CAL is more & & & & \\
\hline 5 & $\begin{array}{l}\text { Mixture of both CAL and graphical illustrations is } \\
\text { required to learn experimental pharmacology }\end{array}$ & & & & \\
\hline
\end{tabular}

